\section{The Effect of Thyroid State, Adrenaline and Glucose on the Release of Free Fatty Acids from Adipose Tissue}

The blood level of free fatty acids (FFA) is low in hypothyroid and high in hyperthyroid patients. The decrease of blood FFA after ingestion of glucose is greater in hyperthyroid than in eu- and hypothyroid individuals ${ }^{1}$. It is generally accepted that glucose lowers the FFA in plasma by decreasing their release from adipose tissue ${ }^{2}$. Considering the possible participation of catecholamines in the manifestations (haemodynamic etc.) of thyreotoxicosis ${ }^{3}$, the study of the relationships between adrenaline and glucose effects on the release of FFA from adipose tissue of hypo- and hyperthyroid rats was undertaken.

Method. 30 female Wistar rats were divided in 3 groups, each containing 10 animals. The first group was euthyroid, in the second group the animals were hypothyroid after total thyroidectomy 2 months prior to termination of experiment. In the third group the hyperthyroid state was elicited by application of 0.1 gdesiccated thyroid (Thyreoidin Spofa) per animal per day for 4 weeks. The state of animals was assayed by measuring the basal oxygen consumption 4 .
The incubation medium was 5\% human albumin (Cohn fraction V) in Krebs buffer without $\mathrm{Ca}^{++}, \mathrm{pH} \mathrm{7.45}$. Concentration of glucose, when used, was $2 \mathrm{mg} / \mathrm{ml}$ and of adrenaline $2.5 \mu \mathrm{g} / \mathrm{ml}$ respectively.

The rats were sacrificed by decapitation and always $200 \mathrm{mg}$ of mesenteric adipose tissue was placed in vessels with $3 \mathrm{ml}$ of incubation medium. The samples for determination of FFA were taken after 5 and $120 \mathrm{~min}$ of incubation at $37^{\circ} \mathrm{C}$ and steady agitation. The FFA concentration was determined by the method of TrouT et al. ${ }^{\circ}$.

Results. From the Table it is evident that the release of FFA from the mesenteric adipose tissue of hypothyroid rats was less $(P<0.05)$, and in hyperthyroid rats it was greater $(P<0.05)$ than in the control euthyroid group. In presence of glucose the release of FFA from adipose tissue to incubation medium was inhibited; in fact the concentration of FFA in medium was lowered in all three groups.

The addition of adrenaline augmented the release of FFA from adipose tissue of hyperthyroid rats as well as from euthyroid rats. In hypothyroid animals there was not observed significant effect of adrenaline. The increase of FFA concentration in incubation medium of hyperthyroid group was significantly greater than that of euthyroid and hypothyroid group $(P<0.01)$.

FFA relcase from rat mesenteric adipose tissue in $\mathrm{mEq} / \mathrm{l}$ incubation medium (mean \pm standard error)

\begin{tabular}{|c|c|c|c|c|}
\hline Group & $\begin{array}{l}\text { Medium } \\
\text { Albumin }\end{array}$ & Albumin + Glucose & Albumin + Adrenaline & Albumin + Adrenaline + Glucose \\
\hline
\end{tabular}

The increased liberation of FFA due to adrenaline was not influenced by addition of glucose in euthyroid group.

In hyperthyroid group the addition of glucose lowered the adrenaline exaggerated release of FFA $(P<0.05)$.

Discussion. The fact that the difference between levels of FFA in albumin medium after $120 \mathrm{~min}$ of incubation with and without glucose was greatest in hyperthyroid group is in good agreement with our human data. The decrease of blood FFA levels after glucose ingestion was greatest in hyperthyroidism ${ }^{1}$.

In accordance with a recent report of DeBons and SchwARTz, it was found that a hyperthyroid state markedly augmented the release of FFA from rat adipose tissue after adrenaline.

The explanation of the antagonizing effect of glucose to adrenaline-enhanced liberation of FFA from adipose tissue in hyperthyroid rats in contradistinction to the euthyroid group, where glucose was ineffective, is not clear at present. However, it should be realized that metabolism of glucose is enhanced in hyperthyroidism ${ }^{8}$. In consequence of this enhanced metabolism of glucose, there could, for instance, be a generation of the glycerol phosphate in adipose tissue at a faster rate which is sufficient to permit re-esterification of fatty acids liberated from glycerides after adrenaline. In euthyroid animals the generation of glycerol phosphate from glucose may not be sufficient in this respect when adrenaline is present. The elucidation of thyroid-adrenaline-glucose interrelationships in lipid metabolism is under study at present.
Zusammenfassung. Die Freisetzung freier Fettsäuren aus dem mesenterialen Fettgewebe von Ratten ist bei hyperthyroiden Tieren grösser, bei hypothyreoiden geringer und wird besonders bei hyperthyreoiden Ratten durch Adrenalin positiv gesteigert. Glukose beeinflusst die durch Adrenalin gesteigerte Abgabe der freien Fettsäuren aus dem Fettgewebe von euthyreoiden Tieren nicht, setzt diese jedoch bei hyperthyreoiden Ratten herab.

V. Felt, B. Schovanec, P. Beneš, F. Plzák, and V. VRBENSKÝ

Research Institute of Endocrinology, Prague (Czechoslovakia), May 28, 1962.

I V. Felt, J. Soumar, and D. ReIChL, Vnitřní lékařstvi, in press.

2 D. ReICHL and V. Felt, Metabolism 9, 807 (1960).

a W. R. Brewster, JR., J. P. IsaAcs, P. F. Osgood, and T. L. King, Circulation 13, 1 (1956).

4 K. Luštinec, Cs. Fysiologie 5,250 (1956).

- H. A. KREBS, Biochem. Z. 217,191 (1933).

a D. L. Trout, E. H. Estes, Jr., and S. J. Friedberc, J. Lipid. Res. $1,199(1960)$.

7 A. F. Debons and I. L. Schwartz, J. Lipid. Res, 2, 86 (1961).

8 H. ElRiCK, C. J. HeAd, JR., and Y. ARAl, J. clin. endocrin. Metab. $21,387(1961)$. 